\title{
O buraco negro da consciência ocidental
}

The black hole of Western consciousness

\author{
Ricardo Seitenfus ${ }^{1}$ \\ Universidade Federal de Santa Maria - Santa Maria - Rio Grande do Sul - Brasil
}

$\diamond$

Resumo: Desde o alvorecer do Haiti em 1804, o Ocidente nunca foi capaz de aceitar, compreender e conviver com os princípios que regem a independência traumática do berco dos Direitos Humanos fundamentais. Razões de natureza política, estratégica, econômica, religiosa e sobretudo cultural - em seu sentido antropológico - encontram-se no cerne dos desencontros do mundo com a única República que conseguiu libertar-se dos grilhões da escravidão e criar uma nação independente.

Palavras-chave: Haiti; Comunidade internacional; Intervenção; Nações Unidas; Fracasso; Incompreensão

\begin{abstract}
From the dawn of Haiti in 1804, the West has never been able to accept, understand and get along with the principles that govern the traumatic independence of the cradle of the fundamental Human Rights. Reasons of political, strategic, economic, religious and especially cultural - in its anthropological sense - reasons are at the core of the conflicts between the world and the only Republic that managed to get rid of the chains of slavery and create an independent nation.
\end{abstract}

Keywords: Haiti; International community; Intervention; the United Nations; Failure; Incomprehension

Tu sabes qual é o problema do Caribe? Ocorre que todo mundo veio fazer aqui o que não podiam fazer na Europa e esta chinfra tinha que ter conseqüencias históricas [...]

(Gabriel Garcia Márquez, Bohemia, Havana, 1979)

Abordar o Haiti significa experimentar dois sentimentos contraditórios: desespero e encantamento. O primeiro surge por variados caminhos. A análise das frias estatísticas sociais e econômicas, o conhecimento de sua história política posterior à independência, o mergulho na insustentável crueza do cotidiano da grande maioria de seu povo ou ainda as relações promíscuas mantidas com alguns parceiros internacionais, sempre dispostos a lhe estender a mão, embora na maioria das vezes se trate do abraço do afogado.

$\mathrm{O}$ encantamento decorre da força doce e risonha de seu Povo, de seu amor sem limites à vida, da inocência bela e elegante de suas crianças, de sua epopeia pioneira e única na luta pelos direitos humanos, de sua estoica e ao que parece infinitamente elástica capacidade para suportar indizíveis condições de sobrevivência, em sua arte multiforme sustentada em uma realidade local a transmitir valores universais, em suas paisagens sublimes e sedutoras a esconder terríveis e recorrentes perigos.

A dicotômica sensação persegue a todos que tentam uma aproximação com o Haiti. Impossível dela se desvencilhar. O olhar acurado sobre o Haiti somente torna-se possível quando afastado o maniqueísmo, as fórmulas feitas e acabadas, as teorias levadas a simplificar

\footnotetext{
1 Professor Titular na Faculdade de Direito da Universidade Federal de Santa Maria. O presente artigo foi extraído de meu livro citado na bibliografia. A versão francesa foi recentemente publicada no Haiti sob o título L'échec de l'aide internationale à Haiti: dilemmes et égarements, Éditions de l'UEH, Port-au-Prince, 2015, 428 p. Ambas versões encontram-se no Kindle Store da Amazon. Ver <www.seitenfus.com.br>.
} 
a indômita, complexa e contraditória realidade; ou seja, quando não se proceda à eleição do preto ou do branco, pois, na verdade, o que predomina é o cinzento das zonas sombrias.

O entrelaçamento do real maravilhoso de Alejo Carpentier com o real contraditório haitiano aconselha que, para aproximarmo-nos de nosso objeto, devemos mergulhar na pele do outro, despojar-nos das ideias préconcebidas, nos afastarmos da aparência que tende a esconder a realidade, divorciarmo-nos da tentação que conduz a conclusões apressadas, estarmos aptos a mais ouvir do que a falar. Somente assim teríamos uma ínfima possibilidade de penetrar nos meandros de uma sociedade fascinante a desafiar, nestes últimos cinquenta anos, tanto os acordes melodiosos quanto os tambores guerreiros da modernidade. Ora, foi uma atitude exatamente inversa a que tivemos ao longo da História, constituindo o principal fio a conduzir nossa desinteligência.

O Haiti vive desde 1986 um conflito doméstico de baixa intensidade. Trata-se da inevitável luta pelo poder entre atores políticos. Ausentes uma situação de guerra civil, ou o risco de crimes coletivos ou ainda a perspectiva de genocídio. Ao contrário. Os índices de violência estão entre os menores da região. A única particularidade desta disputa política consiste no fato de que não são respeitadas as regras do jogo democrático.

O Haiti tampouco constitui uma ameaça aos seus vizinhos. Em 1995 aboliu suas Forças Armadas e dispõe unicamente de uma Polícia Nacional, pobremente equipada e treinada, além de reduzidos efetivos.

Apesar dessas condições, foram enviadas ao Haiti, entre 1993 e 2013, nada menos de sete missões de intervenção militar, policial e civil patrocinadas pelas Nações Unidas (ONU) com o apoio da Organização dos Estados Americanos (OEA). Devido à falta de alternativa e uma percepção caolha dos desafios haitianos, o Conselho de Segurança das Nações Unidas (CSNU) chamou para si a responsabilidade de supostamente "estabilizar" o país. Inclusive a atual intervenção que pretende ser a derradeira, intitula-se Missão das Nações Unidas para a Estabilização do Haiti (MINUSTAH).

O sistema de prevenção de litígios, mormente o das Nações Unidas, não é adaptado às necessidades e ao contexto haitiano. Como explicar senão pela inadaptabilidade sistêmica que tenha sido necessário, num prazo de uma década, fazer com que a ONU retornasse ao Haiti em seis ocasiões com missões de diferentes naturezas?

O Haiti foi historicamente objeto de uma atenção negativa por parte do sistema internacional. Percebido como uma ameaça, é a força que define as relações do mundo com o Haiti e jamais o diálogo. Localizada numa bacia caribenha considerada mare nostrum por
Washington, escassas milhas a separam da ilha rebelde de Cuba, o Haiti também é tributário de seus históricos vínculos com a França. Todos esses supostos parceiros buscam alcançar um único objetivo: congelar o poder e transformar os haitianos em prisioneiros da própria ilha. O receio dos balseiros (ou boat people) que fujam da ilha explica as decisões internacionais em relação ao Haiti. O que se quer é que os haitianos permaneçam no país a qualquer custo.

Ao longo de dois séculos, a presença de tropas estrangeiras se alternou com a de ditadores. O pecado original do Haiti, na cena mundial, é sua liberação. Os haitianos cometeram o inaceitável em 1804: um crime de lesa-majestade para um mundo inquieto. O Ocidente era, na época, colonialista, escravocrata e racista. Sustentava-se com a exploração das terras conquistadas. Assim, o modelo revolucionário haitiano assustou as Grandes Potências colonialistas e racistas. Os Estados Unidos somente reconheceram a independência do Haiti em 1862 e a França exigiu pesada compensação financeira para aceitar essa libertação. Logo, a independência é comprometida e o desenvolvimento entravado. Desde então o mundo nunca soube como tratar o Haiti e resolveu ignorá-lo. Começaram os 200 anos de solidão do Haiti no cenário internacional.

O Haiti é um concentrado dos dramas e dos fracassos da solidariedade internacional. A ONU aplica cegamente o capítulo VII de sua Carta e implanta suas tropas para impor uma operação de paz. Ela justifica-se com a desculpa burocrática que o mandato do CSNU descarta operações que não sejam as militares. As condições haitianas fazem com que, de fato, seu mandato se resuma na manutenção da paz dos cemitérios.

Proporcionalmente ao número de habitantes, o Haiti é o país que supostamente mais recebe ajuda externa, tanto privada quanto pública. O haitiano é, segundo as múltiplas e variadas estatísticas disponíveis, o que mais caro custa à cooperação internacional. Antes do sismo já era assim. Após 12 de janeiro de 2010, o fenômeno ampliou-se de tal maneira que é legítimo interrogar-se sobre as características e os resultados desta "corrida ao ouro" para a indústria da ajuda internacional na qual se transformou o Haiti.

Contrastando com o imenso volume de suposta ajuda concedido, os resultados são pífios. Os programas financiados com recursos externos tendem a desaparecer tão logo repassados aos parceiros haitianos, pois é ausente qualquer vestígio de sustentação. O país faz jus ao título de cemitério de projetos. Pode-se agregar que o Haiti é o país das ilusões e da inocência perdidas, das frustrações infinitas, dos sonhos desfeitos, do purgatório das boas intenções.

A catástrofe atual inscreve-se numa original trajetória histórica. Ao longo desta foram semeadas desgraças e 
feitos heroicos. Marcado por constantes e dramáticas desinteligências com o Ocidente, o Haiti provoca repulsão e medo - traços maiores a impregnar de maneira indelével suas relações exteriores.

O que constituiu o berço da conquista espanhola e logo francesa do Novo Mundo iluminou ao longo dos séculos tanto o que há de mais sublime, quanto o de mais horroroso na condição humana. Foi sob a luminosidade incomparável dos céus caribenhos, a refletir-se em suas águas de um azul intenso, que crimes horrendos foram cometidos. E foi precisamente no berço haitiano que vingou a única revolta dos condenados da terra. Foram das altas terras haitianas que ecoou o grito pela liberdade, pela dignidade, pela justiça e pela igualdade. Todavia antes que ele fosse ouvido, o que dominou os corpos e os espíritos foram os lamentos de uma noite sem fim.

Em 10 de março de 2000, quando visitava Pointe-àPitre (Guadalupe), o Presidente francês, Jacques Chirac, sentenciou que o "Haïti na pas été, a proprement parler, une colonie française...".

O absurdo da frase, embora subentenda a necessidade de explicitar o significado de "proprement parler", integra uma forte corrente de pensamento e de ação, na maioria das vezes subjacente, marcada pelo distanciamento e pela rejeição ao Haiti e ao que ele significa.

A sintomática e constante repulsa francesa ao Haiti impediram que, ao longo de mais de dois séculos, um Chefe de Estado francês visitasse sua antiga colônia. Foi necessário que adviesse o terrível terremoto de 12 de janeiro de 2010 para que Nicolas Sarkozy reparasse o opróbrio.

Embora significativa, a brevidade da permanência de algumas horas e o perfil do Chefe de Estado francês indicam os limites instransponíveis das relações entre Porto Príncipe e Paris. Nicolas Sarkozy é um dos adeptos do revisionismo da história do colonialismo. Em discurso sobre o Homem Africano de fevereiro de 2007, ele sustenta que

Le rêve européen qui fut le rêve de Bonaparte en Egypte, de Napoléon III en Algérie, de Lyautey au Maroc, ne fut pas tant un rêve de conquête qu'un rêve de civilisation. Cessons de noircir le passé de la France. Je veux le dire à tous les adeptes de la repentance: de quel droit demandez-vous aux fils de se repentir des fautes de leurs pères, que souvent leurs pères n'ont commises que dans votre imagination?

Filho bastardo e indesejável de uma colonização promissora que se transforma, com o processo de independência, em catástrofe traumática, o Ocidente se esforça em afugentar de seu horizonte tudo o que se refere ao colonialismo e em particular ao Haiti. Pois, como sublinha um crítico contemporâneo, "le dernier moment de la colonisation consiste à coloniser l'histoire du colonialisme" ${ }^{1}$.

O extraordinário sucesso do modelo colonial francês aplicado em Saint-Domingue e os não menos extraordinários feitos que conduzam ao seu ocaso em 1803 imprimem originalidade a marcar de forma indelével as relações haitianas com o mundo.

$\mathrm{O}$ processo de independência constitui o ápice de um processo político, cultural e psicológico marcado tanto pela rejeição a tudo que representa ou que possa ser assimilado ao Haiti, bem como pelo medo experimentado pelo Ocidente em face da realidade haitiana. Medo atávico que invade e domina a maioria dos estrangeiros quando ousam aproximarem-se do Haiti.

Tal como o rugir de um trovão no céu anilado do colonialismo, a independência do Haiti, portadora da mensagem de igualdade entre as raças, constitui-se em acontecimento insólito.

A revolução haitiana foi percebida pelo Ocidente como absurda e inaceitável. O fato de um grupo de negros escravos e analfabetos infligirem uma derrota ao exército considerado como o mais bem treinado e equipado da época confronta e choca com o espírito do tempo.

Comandadas por Charles Victoire Emmanuel Leclerc - cunhado de Napoleão Bonaparte - quando acosta no Cabo Francês, a Armée du Rhin ainda exala o cheiro da pólvora de múltiplas vitórias conquistadas nos campos de batalhas europeus. Estamos frente a acontecimento pioneiro: pela primeira vez na História um exército branco será derrotado por forças armadas de outra raça ${ }^{2}$.

Os vencidos tentarão apagar da memória coletiva qualquer resquício do desastre. Os vencedores sublimarão o heroico feito transformando-o em certidão de nascimento de uma nação e exemplo a ser seguido pelos povos então colonizados.

A usurpação do recito sobre a evolução da História da Humanidade praticada pelos meios acadêmicos europeus os quais impuseram eurocêntrica, exclusiva e unívoca interpretação, como apontado na obra de Jack Goody ${ }^{3}$, adquire especial relevância no caso haitiano. Aimé Césaire em seu panfleto Discurso sobre o Colonialismo já havia decretado, em 1950, que a Europa é "moral e espiritualmente indefensável".

O objetivo é apagar da memória coletiva qualquer vestígio da responsabilidade do Ocidente na dramática formação da sociedade haitiana. Ao fazê-lo, furta ao Haiti o seu próprio passado. Apropria-se dos princípios mais

\footnotetext{
1 Karl Laske, "Sarkozy, 1'anti-Césaire", in Libération, Paris, 21 de abril de 2008.

2 Tal feito é silenciado pela historiografia das relações internacionais. Esta considera a vitória nipônica na guerra russo-japonesa, em 1905, como sendo a primeira derrota de forças armadas brancas para não brancas.

3 Jack Goody, Le vol de l'Histoire: comment l'Europe a imposé le récit de son passé au reste du monde, Gallimard, Paris 2010, 487 p.
} 
elevados que moveram a revolução haitiana e os transfere para a revolução francesa e americana. A partir de então o Haiti se transforma no buraco negro da consciência ocidental.

Como ressalta Eduardo Galeano em memorável artigo:

Consulte qualquer Enciclopédia e indague qual foi a primeiro país livre da América. Encontrarás sempre a mesma resposta: os Estados Unidos. Mas os Estados Unidos declararam sua independência quando era uma nação com seiscentos e cinqüenta mil escravos, que seguiram sendo escravos durante um século.

Se você pergunta a qualquer Enciclopédia qual foi o primeiro país que aboliu a escravidão, receberás a mesma resposta: Inglaterra. Mas o primeiro país que aboliu a escravidão não foi a Inglaterra e sim o Haiti, que todavia continua expiando o pecado de sua dignidade ${ }^{4}$.

Nesta perspectiva, torna-se imprescindível, como propõe Michel-Rolph Trouillot ${ }^{5}$, reescrever a história da Humanidade nela inserindo o que foi silenciado sobre o Haiti.

De outra banda, surge o paradoxo do discurso da liberdade com a prática da escravidão. $\mathrm{O}$ radicalismo da revolução haitiana coloca em cheque as premissas mais progressistas dos principais pensadores humanistas europeus dos séculos das Luzes. O que havia de mais puro, inovador, revolucionário e humanista, ao confrontarse com as ideias, lutas e dramas provenientes de SaintDomingue, aparece gauche, inconsistente, contraditório e insuficiente.

Não chega a ser uma surpresa constatar que Thomas Hobbes considere a escravidão como "parte inalienável da lógica de poder". 6 Tampouco que John Locke, "como acionista da Real Companhia Africana, envolvida na política colonial americana na Carolina", ${ }^{7}$ a defina como sendo uma instituição justificável. Menos ainda que François-Marie Arouet - Voltaire - enriquecendo-se com especulações na Bolsa de Valores durante o Reinado de Louis XVI, inclusive com ações de companhias que investiam em Saint-Domingue, não tenham manifestado qualquer contrariedade com o regime de escravidão.

\footnotetext{
4 "Haití, país ocupado", in Página 12, Buenos Aires, 28 de setembro de 2011

5 In Silencing the Past: Power and the Production of History, Beacon Press, 1995, $195 \mathrm{p}$

6 In The problem of slavery in the age of revolution, 1770-1823, Ithaca, Cornell University Press, 1975, p. 263

7 Conforme Susan Buck-Morss, "Hegel et Haiti", CEBRAP, São Paulo, julho de 2011, p. 135.

8 Consultar Susan Buck-Morss, "Hegel et Haiti", op. cit. e Pierre-Franklin Tavares, "Hegel et Haiti, ou le silence de Hegel sur Saint-Domingue", Chemins Critiques, Port-au-Prince, maio de 1992, p. 113-131. Do mesmo autor ver "Hegel et l'abbé Grégoire: question noire et révolution française", in Annales historiques de la Révolution française, n. 293-294, 1993, p. 491-509.
}

O inconsistente aparece com o silêncio omisso e conivente de Jean-Jacques Rousseau - defensor intransigente da liberdade - que jamais se referiu aos acontecimentos de Saint-Domingue e sequer mencionou a prática da escravidão na África.

Um exemplo carregado de significados ocorre com Georg Wilhelm Friedrich Hegel. Durante duzentos anos um pesado silêncio pairou sobre suas relações com a escravidão haitiana. $\mathrm{O}$ véu começou a ser levantado recentemente a demonstrar que Hegel não somente inspirou-se na revolução haitiana para elaborar sua obra La Phénoménologie de l'esprit, na qual disseca a dialética das relações entre le maître et l'esclave, como também não esteve imune ao racismo que subjugou seus colegas contemporâneos ${ }^{8}$.

Quando os guardiões da liberdade e da igualdade assim se posicionavam, à revolução haitiana restou tão somente a violência do feito, a desumanidade dos combates e o suposto e injusto radicalismo de um mundo dominado por crendices.

O racista Ocidente cria o sistema colonial que estende, a partir do século XVI, seus tentáculos através do mundo a dominar populações dos demais continentes. Mais do que uma ideia, existe a convicção da inconteste supremacia branca sobre as demais raças. Nestas condições, o Ocidente não está preparado para aceitar, sequer explicar, a indescritível derrota.

Não se trata, além disso, de uma derrota militar qualquer. Ela é carregada de simbologia, pois se contrapõe - pelo exemplo triplamente revolucionário posto que, além da derrota militar e da abolição do sistema escravocrata, os ex-escravos implantam uma República independente às lições das potências coloniais.

Como ressalta Aimé Césaire, o reconhecimento da independência haitiana pela França resulta da batalha entre duas políticas possíveis - a dos princípios contidos em sua própria Revolução e a dos interesses do colonialismo. Apesar de vozes anti-colonialistas, tais como a de Dupont de Nemours, que estigmatiza o racismo que grassa na jovem República francesa ao sustentar que não deve haver hesitação "dans le sacrifice d'une colonie plutôt que d'un principe", não há nenhuma dúvida sobre seu resultado final.

Paris deve reagir pois o caso haitiano pode servir de exemplo e indicar o caminho para a conquista da dignidade dos povos colonizados. O Ocidente colonialista e racista, inspirado pela posição francesa define uma estratégia cuja aplicação se estenderá ao longo dos dois séculos, alcançando os dias atuais. Ela envolve cinco dimensões:

(1) estabelecer um cordão sanitário impedindo ao Haiti estabelecer e manter contatos internacionais; 
(2) enfraquecer o Estado haitiano, tornando o país ingovernável.

(3) criar condições culturais e psicológicas no Ocidente fazendo com que tudo que venha do Haiti seja percebido como um mal em si.

(4) perceber o Haiti como uma sociedade que ameaça os fundamentos das relações internacionais.

(5) alimentar um pavor temeroso e covarde frente ao Haiti.

A iniciativa imediata da ex-metrópole consiste em não reconhecer de jure a independência haitiana. Sem o reconhecimento, o novo Estado encontra-se em um limbo político e jurídico.

Após mais de duas décadas, finalmente, em 1826, firma-se um Tratado entre os dois países. Nele a França exige e obtém uma compensação financeira equivalente a US\$ 21 bilhões de dólares atuais. Imaginando que o rigoroso cumprimento do acordado será um salvoconduto para sua Revolução no Concerto das nações, as autoridades haitianas obrigam-se a buscar empréstimos junto a bancos franceses para honrar o débito. Abrese assim um ciclo de dependência e de endividamento a comprometer seu desenvolvimento econômico e a hipotecar seu futuro.

Os Estados Unidos acompanham a França em sua estratégia de denegação da existência do Haiti. O Presidente Thomas Jefferson declara em 1801 que, no caso em que a ilha alcance a independência, ela deveria permanecer sob a proteção da França, Estados Unidos e Grã-Bretanha. A troïka encarregar-se-ia de isolar o vírus da peste que acomete o Haiti. Para Jefferson, uma simples medida eliminaria qualquer risco de contaminação: "Tant que nous empêcherons les Noirs de posséder des navires, nous pourrons les laisser exister, et continuer à entretenir des contacts commerciaux très lucratifs avec eux"

A estratégia de manter os Haitianos prisioneiros de sua própria ilha, fazendo com que o Mar do Caribe se transformasse em barreira intransponível, impediu que o Haiti jamais dispusesse, ao longo de duzentos anos, de uma marinha mercante. Mais do que instrumento indispensável para integrar-se aos fluxos do comércio mundial, o barco significa intercâmbio de ideias e experiências. Vindas do Haiti, ambas perigosas.

A postura dos Estados Unidos frente à eventualidade de uma Saint-Domingue independente não deixa pairarem a mínima dúvida, pois o "Haïti peut exister comme un grand village de marrons, un quilombo ou un palenque. Il n'est pas question de l'accepter dans le concert des nations" $" 10$.

Em 1820, novamente o tema do reconhecimento do Haiti é debatido no Senado dos Estados Unidos. O representante da Carolina do Sul, Robert Y. Hayne, coloca um termo às discussões ao declarar que "with nothing connected with slavery can we treat with other nations. Our policy with regard to Haiti is plain. We never can acknowledge her independence" 11 .

Sob a batuta do extraordinário Lincoln, os Estados Unidos reconhecerá a independência haitiana em 1862, durante a Guerra de Secessão. A vitória permitirá a abolição de seu próprio sistema escravocrata sem alcançar, no entanto, terminar com a segregação. Meio século depois (1915), supostamente fatigado com a turbulência política, Washington ocupa o Haiti e o transforma em sua colônia.

Bem mais que sua originalidade, o radical tripé revolucionário haitiano impressionou os mestres de um Brasil que se encontrava nos estertores de sua fase colonial. A liberdade alcançada pelos escravos haitianos era considerada uma blasfêmia a ser combatida. Deveria ser impedida qualquer aproximação dos movimentos libertários brasileiros com o perigoso mal. O haitianismo "se tornou expressão que definiria a influência daquele movimento sobre a ação política de negros e mulatos, escravos e livres nos quatro cantos do continente americano [ainda mais que desde 1805] o retrato de Jean Jacques Dessalines decorava medalhões pendurados nos pescoços de milicianos negros no Rio de Janeiro." 12 Para os escravocratas se tratava do mal absoluto a ser extirpado da sociedade brasileira.

Os revolucionários haitianos lançam as premissas dos Direitos políticos fundamentais que embasarão o processo de descolonização a partir da década de 1950. Assim, o princípio da Autodeterminação dos Povos - reivindicado e conquistado a ferro e a fogo pelos revolucionários haitianos - constituirá a pedra de toque das relações internacionais na segunda metade do século passado.

Também nascerão da vitoriosa revolução haitiana o pioneiro e violento clamor na defesa da igualdade da raça humana.

We are black, it is true, but tell us, gentleman, you who are so judicious, what is the law says that the black man must belong to and be the property of the white man? Yes, gentleman, we are free like you, and it is only by your avarice and our ignorance that anyone is still held in slavery up to this day, and we can neither see not find the right that you pretend to have over us. We are your equals then, by natural right, and it nature pleases itself to diversity colors within the human race. It is not a crime to be born black not an advantage to be white ${ }^{13}$.

\footnotetext{
9 In Laurent Dubois, Les Vengeurs du Nouveau Monde, Éditions UEH, Port-au-Prince, 2009, p. 271.

10 Jean Casimir, préface in Ibidem, p.12.

11 Alyssa Golstein Sepinwall (Coordenadora), Haitian history: new perspectives, Routledge, New York, 2012, p. 103.

12 João José Reis, "Nos achamos em campo a tratar da liberdade: a resistência negra no Brasil oitocentista", in Carlos Guilherme Mota, Viagem incompleta: a experiência brasileira, São Paulo, SENAC, 2000, p. 248.

13 Trecho de carta endereçada aos revolucionários franceses, em julho de 1792, por lideranças da Revolução haitiana.
} 
Marcada pela originalidade, pela violência e pela miséria que dela supostamente decorreu, a Revolução haitiana foi transformada em matriz de sentido, ou seja um lócus para "onde convergiram os discursos e representações sobre a escravidão e tudo que dela derivava"14. Ela provocou mudanças no mercado internacional, sobretudo o aumento do preço do açúcar, mas também um incremento das medidas de controle do trabalho escravo: "de Virginia ao Rio Grande do Sul, leis mais rígidas, uma atitude menos tolerante com os homens de cor e um medo generalizado de revoltas escravas mostraram ser o legado social e político da experiência haitiana"15.

Obcecado pela afirmação de sua independência, pelo respeito ao princípio da igualdade racial e enfrentando a hostilidade do mundo, o Haiti jamais conseguirá criar um modelo de Estado de Direito suficientemente forte e justo, capaz de afastar de seu horizonte a anarquia e a ditadura; ao contrário, estas marcarão a história ao longo de seus dois séculos de independência.

Duas características impregnam de maneira indelével as relações do futuro Haiti com o mundo. Por um lado, a bárbara e indiscriminada violência da Conquista, da época colonial e dos anos de luta pela independência, encharcando de sangue a ilha de Espanhola. Por outro lado, as incompreensões decorrentes das crenças míticas e religiosas.

Cristóvão Colombo é seduzido pela beleza de uma vegetação tropical abundante, por ilhas e praias paradisíacas, cercadas por um mar azul-turquesa. Mas, sobretudo, pela afável acolhida dos habitantes. Após um primeiro momento de pânico quando os indígenas fugiram em direção ao interior das terras, logo a seguir retornaram, pois entenderam que os cristãos não provinham da ilha de Carib (ou Caniba) - onde viviam índios que praticavam o canibalismo - mas sim eram "enviados do céu" e presenteavam a todos com formosos objetos. Não houve nenhuma reação hostil, segundo Colombo, porque se trata "da melhor gente do mundo e a mais mansa possível".

Bartolomeu de Las Casas em sua famosa obra denúncia se refere igualmente à "felicíssima ilha de Espanhola" habitada por pessoas "as mais simples, sem maldades, humildes, pacíficas, sem rancores, ódios ou desejos de vingança, obedientes e fidelíssimas aos seus senhores naturais e aos Cristãos".

Prosseguindo em seu reconhecimento do litoral Norte da ilha, Colombo chega no dia 6 de janeiro de 1493 a uma baía onde encontra alguns indígenas e deles

\footnotetext{
${ }_{14}$ Washington Santos Nascimento, "São Domingos, o grande São Domingos: repercussões e representações da Revolução Haitiana no Brasil escravista (1791-1840)", in Dimensões, vol. 21, 2008, p. 129.

15 Herbert S. Klein, A escravidão africana: América Latina e Caribe, São Paulo, Brasiliense, 1987, p. 107.
}

tenta comprar arcos e flechas. Para tanto desembarcam sete marinheiros que encontram aproximadamente cinquenta indígenas. Ora, após concordar com a venda, os indígenas "saíram em disparada aparentemente para buscá-los, mas retornaram com cordas com o objetivo de amarrar os cristãos" e fazê-los prisioneiros. Houve uma rápida escaramuça que resultou na morte de vários índios. Desde então o lugar é conhecido como Golfo ou Baía das Flechas.

O singelo episódio constitui a primeira manifestação de resistência dos indígenas frente à colonização nas Américas. Menos de três meses de presença espanhola no Novo Mundo é suficiente para constatar que a colonização poderá alcançar seu objetivo, mas deverá ser feita a ferro e a fogo. Colombo experimenta o que será a tônica da relação entre cristãos e indígenas. Os espanhóis se veem obrigados a rever sua idílica percepção recolhida nas primeiras semanas. Nos anos seguintes eles se lançarão como relata Las Casas "como lobos, tigres e leões cruéis e famintos" sobre as indefesas presas.

Os massacres, a exploração e o estupro marcam o início da exploração espanhola. Os indígenas logo se convencem que os cristãos, embora não sejam oriundos da ilha de Carib, tampouco provinham do céu. Uma resistência é esboçada, mas prontamente descartada, pois os meios bélicos de que dispõem fazem com que suas guerras sejam "brincadeiras de crianças". Assim, os cristãos com seus cavalos, espadas e lanças fazem das matanças e crueldades seu modus operandi. Las Casas descreve, de maneira crua e vigorosa, o genocídio perpetrado na ilha Espanhola:

\footnotetext{
Os espanhóis entravam nos povoados e faziam pedaços de crianças, velhos e mulheres grávidas. Apostavam entre si para ver quem com uma facada abria ao meio um homem, ou lhe cortava a cabeça ou lhe abria as entranhas. Faziam forcas compridas de treze em treze vítimas, em honra e reverência de Nosso Redentor e dos doze apóstolos, colocando lenha e fogo e os queimavam vivos. Matavam aos líderes queimandoos em fogo lento para que seus alaridos e desesperados tormentos afugentassem suas almas. Eu vi tudo isso e muitas outras ações de homens desumanos, impiedosos e bestas ferozes, extirpadores e inimigos da linhagem humana.
}

A galeria de horrores descrita por Las Casas causou grande impacto e foi acusado de traição na Espanha. Sua obra foi publicada dezenas de vezes nos demais países colonizadores. Contudo, na Espanha foi boicotada até o século XX, dispondo de uma única edição, a de 1645.

Quando se trata de destruir outras culturas o colonizador branco age com rapidez e maestria. Em nenhum outro lugar do Novo Mundo o extermínio da 
população indígena alcançou tamanha velocidade e tão feroz foi como o ocorrido no magnífico cenário da ilha de Espanhola. Assim, aproximadamente seiscentos mil índios serão massacrados, majoritariamente Tainos. Estes legam unicamente a denominação "Haiti" ("país das montanhas" em língua Taino) aos que os vingarão quando da independência.

Em todos os episódios da Conquista os colonizadores se impuseram em diferentes planos: demográfico, político, econômico, cultural, social e religioso. Apesar disso, foi somente nas Antilhas e particularmente na ilha de Espanhola, que a totalidade da população indígena foi varrida do mapa. A tal ponto que, num primeiro momento, em 1513, já se faz necessário trazer indígenas das ilhas vizinhas. Inútil, pois o indígena se recusa à escravidão.

Como os indígenas demonstraram sua inaptidão, Las Casas sugere a utilização da mão de obra escrava disponível na África. Em sua luta para proteger os indígenas ele utiliza um argumento que marcará profundamente a ocupação humana da ilha Espanhola e da qual se arrependerá o restante de sua vida.

Com a frota comandada pelo frei Nicolas de Obando - verdadeiro fundador de Espanhola e seu governador de 1501 a 1509 - chegam alguns negros escravos à Espanhola. Todavia o primeiro verdadeiro carregamento de negros ladinos, falando espanhol, chega à Espanhola em 1505 e seu fluxo aumenta consideravelmente a partir de 1518 .

Logo é decidido que será a partir da Espanhola, onde o irmão de Cristóvão - Bartolomeu - fundara São Domingos, que a Espanha lançará as bases de seu império nas Américas. Contudo há um grande risco, pois quanto mais a Espanha se lança na conquista de novos territórios mais ela coloca em cheque a colonização insular.

O exemplo é paradigmático, pois o extermínio da população nativa de Espanhola e seus recursos naturais saqueados constituem sinais precursores que lançam os Conquistadores em direção aos povos considerados inferiores. Desprovidos de escrúpulos morais ou freios institucionais, reconfortados pela cegueira bárbara do Catolicismo, os Conquistadores encontram via livre material e conforto espiritual para levar adiante o que se tornaria a maior carnificina da história da Humanidade.

A Espanha é péssima colonizadora e excelente exploradora. Os veios de ouro da Espanhola são pobres e se esgotam rapidamente. Logo a seguir descobremse riquezas ao alcance da mão no México e no Peru, contrastantes com a pobreza da ilha em metais preciosos. Os poucos colonos da ilha somente podem oferecer o gado que se multiplica. Contudo o poder espanhol, não satisfeito, impõe taxas abusivas decorrentes de seu monopólio comercial, obrigando os colonos ao contrabando. A situação se degrada a tal ponto que a quatro de agosto de 1603, o rei espanhol Felipe II decide retomar o efetivo controle da economia da ilha. Ele o faz de maneira radical e impensável: ordena o despovoamento do Oeste da ilha e sua concentração na parte Leste. Todas as cidades situadas ao longo daqueles litorais são destruídas. São evacuados escravos e animais. Mutila-se, assim, a economia da parte ocidental da ilha, que se transforma em terra arrasada e de ninguém (terra nullius).

Aproveitando-se da incúria e posteriormente do abandono espanhol, logo chegam à l'île de la Tortue os primeiros piratas de origem francesa e iniciam incursões no território de Espanhola. Trata-se do prenúncio de uma inflexão da história da ilha, pois se utilizando o escudo protetor dos piratas, aporta no atual Haiti, o Estado francês. Não é um Estado qualquer, mas o da potência francesa em seu ápice com Richelieu e Colbert. Surge a colônia francesa denominada de Saint-Domingue.

A ocupação de facto francesa da parte ocidental da ilha é realidade em meados do século XVII. O Direito Internacional europeu a reconhecerá de jure através do tratado de Nimègue (1678) e, sobretudo do Tratado de Ryswick (1697). Consagra-se a divisão da ilha que ainda hoje subsiste. Ocorre, igualmente, uma inversão dos papéis entre as duas partes da ilha: a parte oriental estagna se satisfazendo com a pecuária e com os métodos feudais espanhóis e a parte francesa, por sua vez, se desenvolve de maneira extraordinária graças à pujança do capitalismo francês. A ilha de Espanhola oferece marcante exemplo do embate entre o decadente feudalismo e o dinâmico capitalismo.

Investimentos massivos, melhorias tecnológicas e organização do sistema de produção - denominado cultura de plantação - aplica uma forma racional às extensas terras exploradas através da mão de obra escrava. Além de implantar a cultura do algodão, a França extrai lições do sucesso da cana de açúcar e do café no Brasil e nas demais ilhas das Antilhas e implanta estas duas culturas de maneira sistemática com elevada produtividade.

Em 1720 Saint-Domingue já produzia 21 milhões de libras de açúcar e em 1788 alcançava a impressionante cifra de 52 milhões. Mais de 750 grandes barcos tripulados por 80 mil marinheiros se encarregavam de transportar as riquezas agrícolas da ilha para a metrópole. O futuro Haiti respondia então por mais da metade do comércio exterior da França. Em 1789, por exemplo, dos 17 milhões de libras esterlinas exportados pela França, 11 milhões provinham da colônia de Saint-Domingue.

Tal situação tornou famosa a colônia que passou a ser conhecida como a "Pérola das Antilhas" e muitos investidores acorreram a um negócio extremamente rentável. Empresas foram criadas, ações se valorizavam e trocavam de mãos rapidamente, a ponto de fazer com que personalidades, tais como Voltaire, investissem na economia da ilha. 
No momento da Revolução francesa, frente à massa de escravos, havia tão somente $40 \mathrm{mil}$ brancos e $28 \mathrm{mil}$ libertos, a quase totalidade mulata. No lado espanhol da ilha a situação era completamente distinta. A população total não alcançava $20 \%$ da parte francesa, sendo 35 mil brancos, 38 mil libertos e 30 mil escravos.

Apesar da exiguidade insular, há profunda dualidade na ocupação, na colonização e na história dos dois povos. Culturas, línguas, interesses e comportamento social marcam de maneira indelével um relacionamento turbulento. O contraste entre as duas partes da ilha era total. A espanhola, considerada um parente pobre, e a francesa, dominadora e segura de seu futuro. Nasce então um sentimento de superioridade do haitiano - inclusive na época da escravidão - frente ao seu vizinho. Surge a expressão "pagnol" (contração do vocábulo francês "espagnol") utilizada de maneira pejorativa para designar os brancos pobres espanhóis que vendiam seus animais na parte ocidental da ilha. Comparados aos seus mestres brancos franceses, filhos do período das Luzes, o espanhol e, por extensão, o latino-americano, é menosprezado pelo haitiano. Apesar da terrível evolução da história tal sentimento permanece vivo.

Ao final do século XVIII, aproveitando-se das contradições ziguezagueantes da Revolução Francesa, os revolucionários haitianos reforçam sua capacidade militar e sua determinação na luta pela libertação. Ao longo de uma década de terríveis sofrimentos, atrozes crimes, dolorosas derrotas e memoráveis feitos, finalmente, em 18 de novembro de 1803 , com a definitiva vitória na batalha de Vertières, nasce o Haiti.

Os métodos utilizados pelos contendores de ambas as bandas se adaptam às terríveis experiências da Conquista e da colonização. Eles serão marcados pela luta sem quartel, pelo ódio a turvar a razão, pela constante sede de vingança.

O terror imposto pelas tropas francesas havia sido respondido na mesma moeda. Como declarou Dessalines: "Oui, nous avons rendu à ces vrais cannibales, guerre pour guerre, crimes pour crimes, outrages pour outrages. J'ai sauvé mon pays, j'ai vengé l'Amérique".

Dessalines foi o herói providencial para a terrível missão. Descartando de plano a benevolência que conduziu ao assassinato de Toussaint Louverture - pelo frio e pela fome - no forte de Joux ${ }^{16}$, Dessalines é o homem exigido pelas circunstâncias históricas.

Quando Rochembeau semeia o terror e assassina a quinhentos negros, obrigando-os a cavar sua própria fossa comum, Dessalines não hesita e o faz provar de seu próprio veneno. Sob o olhar incrédulo e apavorado dos colonos franceses, ele crava quinhentos postes nos arredores da cidade do Cabo Francês e a cada um enforca um branco. Deixa-os expostos para que sirvam de lição.
Na principal fonte e referência sobre o uso indiscriminado da violência durante a insurreição haitiana, Bryan Edwards relata que aconteceram

des horreurs que l'imagination ne peut concevoir ni le stylo décrire et produit un tableau de la misère humaine qu'aucun autre pays, à aucune autre époque, n'avait encore exhibé. Plus de cent mille sauvages, habitués aux barbaries de l'Afrique, profitant du silence et de l'obscurité de la nuit pour tomber sur des planteurs paisibles et insouciants, comme autant de tigres affamés et assoiffés de sang humain. La mort guettait le jeune homme comme le vieux, la mère de famille, la vierge et l'enfant sans défense et, en quelques heures funestes, les plaines les plus fertiles et les plus belles du monde sont transformées en un vaste champ de carnage et un désert de désolation ${ }^{17}$.

Complementando o furor de um combate, ausentes regras que não fossem as destinadas a infligir o maior mal possível ao inimigo, os revolucionários lançam mão da tática bélica do incêndio indiscriminado. Logo no início da insurreição, todas as plantações localizadas num raio de oitenta quilômetros em torno do Cabo Francês foram sistematicamente queimadas. Ao final da hecatombe, Saint-Domingue ardia em chamas que transformaram a outrora Pérola das Antilhas em uma montanha de cinzas.

As perspectivas de uma derrota militar radicalizaram os franceses e fizeram com que suas tropas adotassem a tática da guerra de extermínio. Todo Negro, mesmo que demonstrasse fidelidade, era executado sumariamente. No Cabo Francês mil negros são jogados ao mar com um saco de farinha amarrado ao pescoço: "Les jours suivants, la mer rejeta leurs corps sur les plages de la ville où, au dégoût et à l'horreur de ses habitants, on les laisse rôtir sous le soleil équatorial" 18 .

Desesperado, pouco antes de sucumbir à febre amarela em 2 de novembro de 1802, Leclerc informa seu cunhado que "depuis que je suis ici, je n'ai eu que le spectacle d'incendies, d'insurrections, d'assassinats, de morts et de mourants. Mon âme est flétrie, aucune idée riante ne peut me faire oublier ces tableaux hideux" 19 .

O invencível exército de Napoleão, aureolado por suas vitórias nos campos de batalha europeus, foi massacrado por forças que, embora combatam de maneira heroica, são pobremente equipadas, subalimentadas e pouco treinadas. Ao nascer o Haiti encontra-se exaurido.

\footnotetext{
16 Traído pelos franceses em 7 de junho de 1802, Toussaint Louverture é condenado ao desterro. Conduzido à França, ele profetiza ao declarar que "destituindo-me, vocês somente derrubaram o tronco da árvore da liberdade de Saint Domingue. Ela renascerá, pois suas raízes são numerosas e profundas."

${ }^{17}$ In The History, Civil and Commercial, of the British Colonies in the West Indies, Editor J. Stockdale, Londres, 1801, v. 3, p. 67-79, citado por Laurent Dubois, Les Vengeurs du Nouveau Monde, op. cit., p. 140-141.

${ }^{18}$ Laurent Dubois, ibidem, p. 350.

19 Ibidem, p. 351.
} 
Estima-se em mais de 160.000 o número de suas vítimas. Os franceses perderam 43.000 soldados e a totalidade de seus colonos foi massacrada ou teve que abandonar o Haiti. Apesar da vitória, não cessaram os combates, agora como guerra civil. Logo surgem movimentos de secessão que o enfraquecerão ainda mais.

Encarregado, em fins de 1803, da redação do texto anunciando o nascimento do Haiti independente, Louis Felix Boisrond-Tonerre, indica que "pour établir votre acte d'indépendance, il faut de la peau d'un blanc pour servir de parchemin, son crâne pour écritoire, son sang pour encre, et une baïonnette pour plume".

Inspirado assim, o documento fundador do Haiti conclui-se com o grito de "haine éternelle à la France!". Anos mais tarde, prisioneiro na ilha de Santa Helena, Napoléon Bonaparte admite, a contragosto, seu grave erro:

Dans l'intervalle que m'avait laissé la trêve d'Amiens [27/3/1802 - 23/5/1803], j'avais hasardé une expédition imprudente, qu'on m'a reprochée et avec raison, elle ne valait rien en soi.

J'avais essayé de reprendre Saint-Domingue; j'avais de bons motifs pour le tenter: les alliés haïssaient trop la France pour qu'elle osât rester dans l'inaction pendant la paix. Il fallait donner une pâture à la curiosité des oisifs; il fallait tenir constamment l'armée en mouvement pour l'empêcher de s'endormir. Enfin, j'étais bien aise d'essayer les marins.

Du reste, les maladies ont détruit l'armée, l'expédition a été mal conduite; partout où je n'ai pas été, les choses ont été $\mathrm{mal}^{20}$.

Após a independência dos Estados Unidos em 1776 eis que surge novamente no Novo Mundo uma segunda vitória contra o colonialismo europeu. Contudo não haverá contraste mais evidente entre a acolhida entusiasta feita aos revolucionários da América do Norte e o desprezo mesclado de arrogância com os quais serão tratados os libertadores de Saint-Domingue. Para aqueles, a glória. Para estes, o opróbrio. Começam dois séculos de via crucis e de solidão internacional para seu povo.

O processo de colonização marca o início da globalização. Da inevitável descolonização que se desenrolou em etapas históricas ao longo dos séculos XIX e $\mathrm{XX}$ implicou todos os Continentes, surgiram mais de 150 novos Estados que refizeram o mapa político mundial. De todas as experiências, por vezes dramáticas, decorrentes da descolonização, nenhuma alcançou à haitiana. Nenhum Estado, embora nascido a fórceps das lutas de independência, será objeto da rejeição unânime e radical como a que foi objeto o Haiti. Nenhum outro jovem Estado receberá do mundo o tratamento iníquo que será infligido ao berço dos Direitos Humanos fundamentais.
Avançado para o seu tempo, o Haiti teve razão demasiado cedo. Então, debilitada internamente e abandonada em suas relações externas, são incertas as perspectivas de êxito da Primeira República Negra constituída por ex-escravos.

No alvorecer da independência, todavia restava uma esperança. Para romper seu isolamento os líderes da Revolução haitiana tomam consciência de que deverão buscar apoios internacionais junto aos movimentos de independência que surgem na América ibérica. A aproximação haitiana com os revolucionários latino-americanos insere-se tanto em uma lógica de solidariedade em torno de princípios, quanto na de sobrevivência. Contudo, Porto Príncipe logo cometerá o erro imperdoável de tentar transformar a vitória de 1804 em produto de exportação.

A oportunidade se apresenta em dezembro de 1815. Encurralado, deprimido e à beira do suicídio, um desesperado Simon Bolívar encontra refúgio na Jamaica. Decide, então, aceitar o convite do presidente Alexandre Pétion e viaja a Les Cayes com o que resta de sua frota recentemente derrotada pelos espanhóis em Cartagena das Índias.

Bolívar recebe apoio do presidente Alexandre Pétion e de alguns comerciantes estrangeiros. Reúne homens, navios e armamento no Haiti e lança, em maio de 1816, uma expedição na costa Leste da Venezuela. Uma vez mais Bolívar é derrotado em julho de 1816. Então, retorna ao Haiti e, desesperado, escreve a Pétion solicitando novamente auxílio. A resposta seria aguardada como sendo, segundo Bolívar,"le dernier décret de ma vie politique".

Reconhecido, Bolívar escreve uma carta a Pétion em nove de outubro de 1816. Nela, enfatiza que o Presidente haitiano

possesses a quality which is above empires, named altruism. It is the President of Haiti alone who governs for the people. It is he alone who leads his equals. The other potentates, content to make themselves obeyed, scorn the love which makes your glory. The hero of the North, Washington, found only enemy soldiers to conquer. Your Excellency has all to conquer, enemies and friends, foreigners and countrymen, the fathers of the country and even the strength of his brothers. This task will not be impossible for Your Excellency, who is above his country and his epoch ${ }^{21}$.

Os arsenais haitianos outra vez armam Bolívar com fuzis e munição. Trezentos combatentes haitianos

\footnotetext{
${ }^{20}$ In Manuscrit venu de Sainte-Hélène, Ed. Badouin Fils, Paris 1821, p. 45.

${ }^{21}$ In Dantes Bellegarde, "President Alexandre Petion: founder of Agrarian Democracy in Haiti and Pioneer of Pan-Americanism", Phylon, v. II, n. 3, 1941, p. 213.
} 
juntam-se à empreitada. Ao comando de uma frota de oito navios, o futuro Libertador zarpa para a Venezuela em 28 de dezembro de 1816 ao encontro, finalmente, de sua sonhada vitória.

Ausente o apoio haitiano, impossível seria a vitória de Bolívar. Este o reconhece e indaga Pétion sobre a conveniência de considerá-lo como "o Autor da liberdade Americana". O Presidente haitiano jamais respondeu. No entanto, fazia uma única exigência: uma vez alcançada à sonhada independência, os Libertadores se comprometessem em abolir a escravidão.

Promessa feita. Promessa descumprida. Os novos mestres eram tão escravocratas quanto os antigos senhores e fizerem ouvidos de mercador aos apelos haitianos.

Os Libertadores temiam o possível contágio das ideias e da violência de Santo Domingo. A vitória dos affranchis e dos escravos haitianos constitui sinal de alerta para os escravocratas das Américas e uma advertência sobre as temíveis consequências da propagação, nas sociedades escravocratas, das ideias liberais de igualdade e de direitos humanos.

Quando da convocação do Congresso do Panamá em 1826 que objetivava lutar contra a dispersão e a favor da integração da América Latina, Simon Bolívar surpreendentemente convida os Estados Unidos, que imediatamente declina a oferta.

A participação haitiana no conclave, sem o apoio do qual teria sido impossível à libertação da América hispânica, sequer é cogitada. Não constitui surpresa seu descarte. $\mathrm{O}$ episódio marca a definitiva marginalização do Haiti dos assuntos continentais. Fecha-se assim, o círculo em torno da turbulenta República negra e tem início duzentos anos de solidão haitiana nas relações internacionais.

Quando o mundo rompe o isolamento haitiano o faz com o exclusivo objetivo de castigar o país e ao seu povo. Invasões, ocupações, agressões e embargos são os métodos utilizados. O Haiti ainda não terminou de pagar o tributo pela ousadia de 1804 .

Raros foram os que perceberam na Revolução haitiana uma esperança para os condenados da Terra. De Cuba ao Brasil, passando pela Jamaica, sussurros de elogios foram logo abafados pelos escravocratas. Alguns intelectuais tentaram dar eco às lições vindas do Haiti. Inutilmente. Embora tenham sido os vales e montanhas haitianas a abrigaram o verdadeiro início da internacionalização dos Direitos Humanos, foram suas irredutíveis adversárias - a revolução americana e francesa - que receberam as láureas de redentoras dos povos, consideradas desde então como Mães da liberdade.

Foi a Revolução haitiana que obrigou a Revolução francesa a tentar cumprir o seu princípio basilar que considerava que os homens nascem e permanecem livres e iguais em direitos. Contudo, esta s'était comme empressée de maintenir l'esclavage des noirs derrière le paravent du droit de propriété, de réconcilier son dire et son faire, ses principes et ses pratiques, et de sortir ainsi d'une fâcheuse et gênante contradiction entre l'idéal proclamé et des intérêts à sauvegarder. Ce fut un coup de maître, mais aussi un fier et signalé service rendu par les nègres insurgés de Saint-Domingue-Haïti à la Grande Révolution Française des Mirabeau, Lafayette, Danton, Robespierre, des Camille Desmoulins et des SaintJust, en la rendant plus conséquente avec elle-même et de portée enfin vraiment plus universelle ${ }^{22}$.

Em seu terrível e violento combate pela independência, as lideranças revolucionárias apelaram ao sobrenatural. O vodu foi um extraordinário cimento para a coesão social durante a época da escravidão e um formidável instrumento de mobilização quando da luta pela libertação. Ainda hoje dominante, o vodu se recusa a render-se à modernidade.

Em 1943 Alejo Carpentier visita o Haiti e sente "o nada mentido sortilégio de suas terras" ${ }^{23}$. Ele descobre quando

pisava uma terra onde milhares de homens ansiosos de liberdade acreditaram nos poderes licantrópicos de Mackandal, ao ponto que esta fé coletiva produzirá um milagre no dia de sua execução... que com essa magia, alentou uma das sublevações mais dramáticas e estranhas da História.

A publicação de seu marcante, embora breve, romance O Reino deste Mundo sobre a independência haitiana é aberto com um Prólogo em forma de manifesto no qual ele lança as bases teóricas do real maravilhoso. Com ele Carpentier se afasta da artificialidade do surrealismo, do qual ele havia sido um dos principais defensores.

Para Carpentier a revelação do Haiti constitui tão somente a fagulha que ilumina a verdadeira identidade e originalidade do continente, pois a América "está longe de haver esgotado seu caudal de mitologias". Para ele a dramática

singularidade dos acontecimentos, pela fantástica postura dos personagens que se encontraram na encruzilhada mágica da cidade do Cabo Francês [hoje Haitiano], tudo resulta numa maravilhosa história impossível de acontecer na Europa e que é tão real, como qualquer acontecimento exemplar daqueles consignados, para pedagógica edificação, nos manuais escolares. Mas o que é a história de toda a América senão uma crônica do real maravilhoso?

\footnotetext{
${ }^{22}$ Leslie François Manigat, Haïti dans la latinité, sens et non-sens, tours er détours, enjeu. Ed.Educam, Rio de Janeiro, 2005, p. 80.

${ }^{23}$ Alejo Carpentier, El Reino de este mundo, Edição Primer Festival del Libro Cubano, Lima, 1948, 122 p.
} 
Como proceder para entender o Haiti, quando se é um intelectual agnóstico dotado de estrutura mental que descarta a priori qualquer referência ao divino e ao sobrenatural? Para Carpentier a tarefa é impossível, pois a sensação do maravilhoso pressupõe uma fé. Os que não creem em santos, afirma ele, "não podem curar-se com seus milagres".

A avaliação de Carpentier é corroborada pelo historiador liberal haitiano Leslie Manigat para quem o Haiti e a terra da irracionalidade, da razão contraditória e embebida de forte densidade mística.

Decepcionado com as superficiais percepções ocidentais, Manigat propugna que seria necessária uma grande evolução da crítica histórica das ciências humanas, para que o Ocidente seja capaz de elucidar o verdadeiro sentido da história haitiana.

Esta avaliação não resulta de uma análise apressada e impressionista. Ela é fruto das reflexões e experiências de alguém talhado para afastar de seu campo analítico elementos e valores capazes de torná-lo opaco. Ora, não somente ele não os afasta, ao contrário, os convoca, considerando-os elementos estruturais da realidade social e política haitiana.

A força do misticismo que impregna e domina a misteriosa sociedade haitiana adquire tamanha amplidão e profundidade que até o observador mais desatento não deixa de percebê-la. Ela está presente tanto nos gestos mínimos quanto nos momentos graves da vida de cada haitiano.

O controle social numa sociedade desprovida de instituições estatais - caso do Haiti - pode ser realizado através da violência - relativamente baixa tendo em conta as disparidades sociais e a miséria absoluta na qual sobrevive a maior parte da população - ou por meio de instrumentos informais de dominação e subjugação: constituição de clãs; formação de clientelas; redes de apadrinhamento, etc. Estes instrumentos de controle são eficientes, embora parciais e limitados. Há somente uma estrutura generalizada e de total eficácia: a religião, pois como enfatiza Victor Turner em clássica asserção, "onde avultam os conflitos, superabundam os rituais".

$\mathrm{O}$ conjunto destes dois elementos - violência e misticismo - fazem com que a baixa literatura e a indústria cinematográfica de Hollywood o transformassem no território dos interditos, do sobrenatural, do incompreensível e logo do inaceitável.

Frente às desinteligências carregadas de preconceitos, o Haitiano adotou a tática dos escravos fugitivos. Definiu uma estratégia de sobrevivência na qual a marronagem transformou-se em filosofia social e em prática política.

O terremoto de 12 de janeiro de 2010 provocou a destruição da Catedral de Porto Príncipe, da maioria das Igrejas e escolas católicas localizadas na região metropolitana e a morte do Arcebispo, Monsenhor Serge Miot. A hecatombe deixou a Igreja Católica de joelhos e abriu caminho aos evangélicos. A partir do sismo, uma invasão silenciosa de congregações, seitas e grupos supostamente religiosos - vindos, sobretudo do meio-oeste dos Estados Unidos - desembarca no Haiti. Desde meados de 2010 não há voo proveniente dos Estados Unidos que não descarregue sua leva de turistas de Jesus, facilmente identificados pela camiseta de sua congregação ${ }^{24}$.

A Embaixada dos Estados Unidos em Porto Príncipe calcula em aproximadamente a incríveis 200.000 o número de seus nacionais que anualmente aportam ao Haiti. Entre estes a grande maioria compõe-se de jovens turistas da fé. Permanecem durante uma semana em um vilarejo construído por sua igreja em convívio com crianças haitianas, na fabricação de artesanato ou de próteses para as vítimas do terremoto. E, sobretudo, oram.

Por vezes motivados pelo arrependimento, pois “j'ai tellement péché cette année en ville, j'espère que, en aidant les pauvres, je vais me réconcilier avec Dieu".

Ou buscando encontrar sentido a suas vidas, os evangélicos confessam que viajam ao Haiti com um único objetivo: fazer com que os haitianos tenham uma nova relação com Jesus Cristo.

Brad Johnson, diretor da Mission of Hope, indica que a quantidade de templos voduistas diminui na região. Aqui, diz ele, "il y a une bataille spirituelle qui se livre ici. Elle existe partout, aux Etats-Unis aussi, où nous adorons l'argent. Mais en Haïti, elle est plus évidente parce qu'ils adorent Satan".

O vodu declara um turista da fé, "ce n'est pas un juste chemin pour ce peuple. Je voudrais tellement les introduire au message de Jésus".

Logo adiante, um sacerdote vodu responde:

\begin{abstract}
Mais ils ne comprennent pas que, nous aussi, nous croyons en Dieu. Ils affirment que nous vénérons le diable et que nous sommes cannibales, ce n'est pas vrai. J'aimerais bien les accueillir pour leur montrer notre culture et que les gens, quand la prière ne marche pas, viennent ici se faire soigner par nos plantes.
\end{abstract}

Raras são as vozes haitianas que protestam. Ocorre que junto às rezas e cânticos, os evangélicos aportam medicamentos e alimentos. Erol Josué, Directeur du Bureau national d'ethnologie d'Haïti, os critica severamente:

\footnotetext{
${ }^{24}$ Consultar Arnaud Robert, "Les touristes de Jésus", in Le Temps, Genebra, 12 de janeiro de 2013, p. 3. Todas as citações são extraídas deste artigo.
} 
La façon dont les évangélistes américains opèrent relève du néocolonialisme. Ils croient conquérir l'âme du peuple haïtien avec un repas chaud. C'est une atteinte à l'identité nationale, à notre tradition ancestrale du vodou. Ils bénéficient des débats sans fin de nos politiciens, qui abandonnent tout l'espace à ces prosélytes.

Josué não deveria desesperar-se. Por ora o relacionamento sustenta-se em uma troca: por um lado, os evangélicos se concedem boa consciência e fornecem bens reais indispensáveis. Por outro, os haitianos dão aparentes demonstrações de abandonar sua crença secular. Para os primeiros se trata de um mercado das ilusões e para os segundos de um mercado dos enganos. Ou seja, o clássico marché de dupes.

Os evangélicos norte-americanos, a começar pelo tele-evangelista Pat Robertson, aproveitam o sismo para retomar, com maior fúria, seus constantes assaltos contra o vodu. Para eles o Haiti é uma terra diabólica, onde imperam as forças do mal. Para Robertson a "maldição" haitiana resulta de um "pacto com o diabo" feito pelos líderes da revolução para liberarem-se do império colonial francês.

Segundo Robertson, "you know, something happened a long time ago in Haiti. They got together and swore a pact to the devil. They said, 'We will serve you if you get us free from the French'. True story"25

Para Robertson o terremoto constitui a maior e mais inquestionável prova do mal que corrói o Haiti. Ele aconteceu unicamente para castigar os haitianos e fazer seu país expiar por seus pecados. Portanto, não se trata de uma manifestação da natureza, tampouco devem ser levadas em consideração as falhas geológicas que atravessam o Haiti. Ao contrário. O sismo decorre de uma vontade de Deus. Do Deus de Pat Robertson e dos evangélicos que invadem atualmente a terra de Dessalines.

Frente aos insultos racistas, desapiedados e absurdos do suposto pastor, o porta-voz da Casa Branca, Robert Gibbs, foi cortante: "It never ceases to amaze, that in times of amazing human suffering somebody says something that can be utterly stupid".

Infelizmente a estupidez corre mais célere que a inteligência, a sensibilidade e o respeito. O Cônsul haitiano em São Paulo, George Samuel Antoine, também culpou o vodu pelo terremoto. Desconhecendo estar sendo

\footnotetext{
${ }^{25}$ Em 14 de agosto de 1791 , em reunião liderada pelo cimarron jamaicano Boukman, ocorrida em Bois Caïman, arredores do Cabo Haitiano, é sacrificado um porco crioulo e seu sangue distribuído aos escravos que dela participavam. Forja-se assim a aliança de sangue pela independência. Boukman faz a todos prestar o seguinte Juramento: "Deus que criou a Terra; que criou o Sol que nos dá a luz; Nosso Deus que nos escuta. Tu observas como os brancos nos fazem sofrer. O Deus do homem branco ordena cometer crimes. Nosso Deus que é bom, que é justo, nos ordena vingança. Ele dirigirá nossa luta e nos levará a vitória...”. Uma semana após a cerimônia, tem início à revolta que culminará na independência 13 anos mais tarde.
}

gravado, ele confidencia: "Acho que de tanto mexer com macumba... o africano em si tem uma maldição... todo lugar que tem africano está fodido... A desgraça de lá está sendo bom para a gente aqui ficar conhecida".

O comentarista do Jornal Nacional da Rede Globo de Televisão, Arnaldo Jabor, ao dissertar sobre o terremoto também toma o caminho pavimentado pelo insulto e pela ignorância. Ele indaga como fazer para "democratizar um país miserável, analfabeto e com raízes tribais africanas e bárbaras?".

A pertinência da pergunta se esfuma com a assertiva contida na parte final. Ninguém se encontra mais distante do tribalismo e da barbárie do que o Haiti.

O que a Igreja Católica não alcançou ao longo de quatro séculos de lutas, os Evangélicos pretendem consegui-lo graças ao impacto provocado pelo terremoto. A luta será inglória. Logo constatarão que o vodu, mais do que uma crença, constitui elemento profundamente enraizado na cultura e na alma haitiana.

Sociedade livre de tabus, a começar por aqueles impostos pelas religiões, à antropologia haitiana pode-se aplicar o lamento de um Bispo católico, personagem de Gabriel Garcia Márquez em Del amor y otros demonios, sobre as incertezas que circundam sua missão: "Hemos atravesado el mar oceano para imponer la Ley de Cristo, y hemos logrado en las misas, en las procesiones, en las fiestas patronales, pero no en las almas".

A extraordinária reação dos haitianos frente à catástrofe provoca ao olhar estrangeiro, além da piedade e da compaixão, uma tentativa de interpretação. Surge com o selo do inquestionável posto que, além de ser uma visão exógena, pretende ser também um elogio. Assim, ao descobrir que os haitianos possuem uma surpreendente capacidade de recuperação, os observadores estrangeiros cunham a expressão resiliência como sendo um dos traços marcantes de seu caráter nacional. Ela deve servir de chave-mestre para compreender o incompreensível, para facilitar a aproximação cultural, para tornar inteligível uma realidade indômita. Como provas, exemplos são pinçados ao longo da atribulada história do país.

A incompreensão prossegue. Muito além da capacidade de recuperar-se frente aos desmandos dos homens e da fúria da natureza, o que move o povo haitiano é uma vontade, uma capacidade de luta, um amor sem limites à vida, sem ilusões e sem renúncias. Da condição humana, os haitianos extraem sua essência que não é outra senão o apego à vida, em suas plenitude e totalidade.

Os haitianos são dotados de uma grande riqueza de vida interior dominada por forte afetividade e espírito de fraternidade. Como se esse excedente da alma viesse a compensar o que o corpo padece.

$\mathrm{O}$ escritor e ativista político Lyonel Trouillot aprofunda a análise sobre os desencontros e dissensões. Para 
ele a primeira entre todas as "injustiças" cometidas com seu país está a que, "concernant Haïti, on écoute plus les Occidentaux que les Haïtiens eux-mêmes"26.

Ao adotar uma radical atitude etnocêntrica, o mundo obriga os haitianos ao silêncio. Sobre si e sobre os outros. Jamais um haitiano define o Canadá, a França, os Estados Unidos. Mas são legião as definições e preconceitos dos canadenses, franceses e estadunidenses sobre o Haiti. Surge o que Trouillot denomina de l'autorité discursive. Para ele, "rien n'est plus terrible pour un peuple que de perdre la capacité de se nommer lui-même".

Colocando-se aquém da grande maioria ocidental que propõe leituras etnocêntricas e ensina lições fadadas ao fracasso, há os que são impressionados pelo Haiti. Pessoas de boa vontade logo se encontram desarmadas quando colocadas frente a uma realidade que não esperavam. O jornalista Tonico Ferreira da Rede Globo de Televisão foi enviado ao Haiti em outubro de 2004 e no seu retorno publicou um revelador embora curto texto no jornal $O$ Globo sob o título:

\section{Confesso: não estava preparado para ir ao Haiti}

E eu até pensei que estava. Havia lido tudo o que podia sobre o país e havia tomado as providências obvias de sobrevivência em um país em clima de guerra civil: vacinas, repelente, barrinhas de cereal, nozes, etc. Eu não estava era preparado emocionalmente para conviver com tanta miséria e sofrimento humano. E tenho certeza que ninguém está.

Se olhar para uma pessoa com fome já é triste, como reagir frente a uma criança que te pede uma garrafa de água?

Se é insuportável viver numa cidade onde não há coleta de lixo, o que dizer dos corpos dos mortos em tiroteios que não são recolhidos e apodrecem nas ruas?

As cidades não têm saneamento, a água é só de bica, para cozinhar, só carvão vegetal, e eletricidade é para quem tem gerador a diesel.

Não era para ser assim. Na verdade, o Haiti foi um exemplo ao nascer. A primeira república negra do mundo, fundada por escravos que derrotaram um exército de Napoleão. Mas as coisas começaram a dar errado logo em seguida. De um lado, o boicote das potências escravistas; de outro, o desentendimento dos revolucionários ao chegar ao poder. Em duzentos anos, desde a independência, o Haiti teve um imperador, um rei e nove presidentes eternos. Todo político que chega ao poder, mesmo aquele inicialmente bem intencionado, quer ficar para sempre.

Há um esforço da Comunidade Internacional para ajudar o Haiti. Nada mais justo. Os antepassados dos haitianos que hoje passam fome foram arrancados de suas aldeias na África e levados para o inferno do trabalho escravo. Morreram trabalhando para suprir o mundo de açúcar. A conta está aí para ser paga.

Nas duas semanas que estive lá, o sentimento de tristeza era dividido com o de revolta interna e com o de repugnância. Aqui no Brasil sobrou só a tristeza na sua plenitude.

Queria terminar com uma frase otimista: falar da música fantástica que ouvimos lá, da beleza e força da cerimônia Vodu que vimos, do sorriso das mulheres nas ruas, das crianças com uniformes limpinhos...

Mas só sinto angústia.

Desculpem-me. Eu não estava preparado para o que vi.
Apesar de alguns escorregões, a qualidade do texto e a sinceridade de um autor movido por louváveis intenções revelam, uma vez mais, as insuperáveis dificuldades para compreender o incompreensível, para superar a desinteligência, para transcender a dura e sublime realidade percorrendo o caminho que conduz do coração à razão.

Calejado por tantas batalhas feitas ao Blanc significado de todo e qualquer estrangeiro - o indomável Haiti tece terríveis e traiçoeiras armadilhas também aos olhares imprudentes que o perscrutam. Feitas de astúcias, de dissimulações, de malandragens, de manobras de diversão, de ardis, de estratagemas, de tergiversações e de impudência. Estratégias de sobrevivência indispensáveis frente aos seus poderosos inimigos.

Separar o verdadeiro do falso, a aparência da realidade, a palavra do pensamento, a marronagem da ação e o sentimento da razão, se constitui em desafio constante. Sem vencê-lo impossível esperar apreender os contornos desta extraordinária e original sociedade.

Contudo, a Comunidade Internacional não pretende compreender, muito menos aceitar, uma realidade contraditória. Ela busca simplesmente estabilizar um poder político instável, normalizar um país anormal e fazer com que os parâmetros da democracia representativa se imponham. Ao desprezar as raízes sociológicas e antropológicas haitianas, a missão se torna impossível.

\section{Referências}

BELlEGARDE, Dantes. President Alexandre Pétion: founder of Agrarian Democracy in Haiti and Pioneer of Pan-Americanism. Phylon, v. II, n. 3, p. 213, 1941.

BONAPARTE, Napoléon. Manuscrit venu de Sainte-Hélène. Paris: Ed. Badouin Fils, 1821.

BUCK-MORSS, Susan. Hegel e Haiti, CEBRAP, São Paulo, jul. 2011, p. 135 .

CARPENTIER, Alejo. El Reino de este mundo. Lima: Edição Primer Festival del Libro Cubano, 1948. 122 p.

DUBOIS, Laurent. Les Vengeurs du Nouveau Monde. Port-auPrince: Éditions UEH, 2009. p. 271.

EDWARDS, Bryan. The History, Civil and Commercial, of the British Colonies in the West Indies. Londres: Editor J. Stockdale, 1801. v. 3.

GALEANO, Eduardo. Haití, país ocupado. In: Página 12, Buenos Aires, 28 sept. 2011.

GOODY, Jack. Le vol de l'Histoire: comment l'Europe a imposé le récit de son passé au reste du monde. Paris: Gallimard, 2010. $487 \mathrm{p}$.

HOBBES, Thomas. The problem of slavery in the age of revolution, 1770-1823. Ithaca, Cornell University Press, 1975.

\footnotetext{
${ }^{26}$ Lyonel Trouillot, "Concernant Haiti, on écoute plus les Occidentaux que les Haïtiens eux-mêmes", in Jeune Afrique, 9 de janeiro de 2012.
} 
LASKE, Karl. Sarkozy, l'anti-Césaire. In: Libération, Paris, 21 avril 2008.

MANIGAT, Leslie François. Haïti dans la latinité, sens et nonsens, tours er détours, enjeu. Rio de Janeiro: Ed. Educam, 2005.

REIS, João José. Nos achamos em campo a tratar da liberdade: a resistência negra no Brasil oitocentista. In: MOTA, Carlos Guilherme. Viagem incompleta: a experiência brasileira. São Paulo: SENAC, 2000.

ROBERT, Arnaud. Les touristes de Jésus. In: Le Temps. Genebra, 12 janv. 2013, p. 3.

SEITENFUS, Ricardo. Haiti, dilemas e fracassos internacionais. Ijuí: Editora da Unijuí, 2014. 464 p.

SEPINWALL, Alyssa Golstein (Coord.). Haitian history: new perspectives. New York: Routledge, 2012.
TAVARES, Pierre-Franklin. Hegel et Haiti, ou le silence de Hegel sur Saint-Domingue. Chemins Critiques, Port-au-Prince, p. 113-131, mai 1992.

TAVARES, Pierre-Franklin. Hegel et l'abbé Grégoire: question noire et révolution française. In: Annales historiques de la Révolution française, n. 293-294, p. 491-509, 1993.

TROUILLOT, Lyonel. Concernant Haïti, on écoute plus les Occidentaux que les Haïtiens eux-mêmes. In: Jeune Afrique, 9 janv. 2012.

TROUILLOT, Michel-Rolph. Silencing the Past: Power and the Production of History. Beacon Press, 1995, 195 p.

Recebido: 02 de agosto de 2015

Aprovado: 21 de setembro de 2015

Contato: independencia@viavale.com.br 